\title{
THE NATURE OF THE LOWERED RESISTANCE TO INFECTION IN DIABETES MELLITUS ${ }^{1}$
}

\author{
By ALEXANDER MARBLE, HAROLD J. WHITE aNd ALISON T. FERNALD \\ (From the George F. Baker Clinic, New England Deaconess Hospital, Boston)
}

(Received for publication March 3, 1938)

That patients with diabetes have less resistance to infection than do normal individuals is a fact met with in the every-day experience of the clinician. Particularly common in diabetics are staphylococcic and streptococcic infections of the skin, $B$. coli infections of the urinary tract, and tubercular infections of the lungs. To be sure, since the introduction of insulin in 1922 and of protamine insulin in 1935, treatment has been so improved that excellent control of the diabetic condition is possible with almost all patients and the resistance to infection in well-controlled cases appears to approximate the normal. However, prior to 1922 and today in patients whose diabetes is poorly controlled, the lessened ability to cope with infections cannot be denied.

In the infections of the feet of elderly diabetics the factor of diminished blood supply resulting from arteriosclerosis is no doubt largely responsible for the slowly healing, non-healing, or gradually extending nature of such lesions. However, allowing for this factor of poor circulation, the nature of the lowered resistance to infection still remains to a large extent unexplained. It is the purpose of this paper to present data bearing upon this point.

Various factors suggest themselves as the cause of the lowered resistance to infection in the diabetic. These may be summarized as follows:

(1) Increased sugar content of blood and tissues.

(2) Decreased activity of blood elements associated with resistance to infection: (a) Subnormal activity of complement; (b) Subnormal phagocytizing capacity of leukocytes; (c) Subnormal bacteriostatic and bactericidal action of whole blood.

(3) Inadequate functioning of fixed tissue cells.

1 The expense of this investigation was met in part by a grant from the Proctor Fund of Harvard University.
(4) Lowered capacity of tissues to react to antigenic stimuli.

(5) Lowered state of general cellular nutrition.

\section{LITERATURE}

One of the earliest ideas and one which is occasionally advanced even today is that the increased sugar content of the blood and tissues seen in diabetes provides a more favorable culture medium, particularly for staphylococci. Such a view was held by Lassar (1), for example. Present-day opinion does not favor this explanation. Thus Handmann (2) found that in vitro, blood containing 0.5 to 1.0 per cent sugar was no better culture medium for staphylococci than normal blood and that the addition of dextrose to blood within the limits found in diabetes did not decrease the bactericidal power of the blood or affect its opsonic index. Hirsch-Kauffmann and Heimann-Trosien (3) observed that streptococci, pneumococci, and influenza bacilli grew better on blood agar plates made with blood from a patient in diabetic coma than on ordinary blood agar, but there was no effect from hyperglycemic blood from non-coma cases, from the addition of dextrose and acetone in vitro, or from cases of experimental hyperglycemia, lipemia, and acidosis. It is true that Kestermann and Knolle (4) reported that by the addition of sugar to normal serum in amounts which are found in the blood of diabetic patients, the bactericidal effect of the serum toward colon bacilli could be appreciably reduced. However, in similar experiments with staphylococci and streptococci such results were not obtained. It is possible that in the case of the colon bacilli, growth of the bacteria was favored by the enriched medium rather than by any lessened bactericidal power of the serum.

Although Pillsbury and Kulchar (5) working with induced staphylococcic skin infections in rabbits found that the frequent injection of hypertonic dextrose solutions caused an increase in the lesion, they believed that the dehydration resulting from the injections of the hypertonic solutions rather than the dextrose itself was the responsible factor. The same type and degree of increase of the lesion could be produced by injections of hypertonic salt solutions. Polyuria and dehydration (accompanying prolonged and marked glycosuria) are regarded by Mosenthal (6) as responsible for the diminished resistance to infection seen in diabetes. $\mathrm{He}$ as well as Bayne-Jones (7) and Richardson (8) considers hyperglycemia per se as of little or no significance in this connection, although all will agree that in general an 
elevated blood sugar must be considered as a sign of uncontrolled diabetes and as the forerunner of acidosis.

Richardson (9) with diabetic patients and Horster (10) with depancreatized dogs found that the amount and activity of the complement of the blood serum did not differ from that of normal blood. Bayer and Form (11) noted, however, that following pancreatectomy there was a decrease in hemolytic complement which could be temporarily restored to normal by the injection of insulin and dextrose.

DaCosta and Beardsley (12), continuing the work of DaCosta (13), found, using Wright's technique, that with staphylococci, streptococci, and tubercle bacilli, the opsonic index of the blood of 50 diabetic patients was approximately one-third below normal. A high degree of glycosuria was found to imply a low grade of bacterial resistance as indicated by the opsonic index. Particularly with the tubercle bacillus, acidosis (which was present in 15 of the 50 cases) was associated with a low opsonic index. It must be remembered that DaCosta's studies were carried out in 1908 before the time of insulin. Sisto (14) using the same technique obtained in 1911 results similar to those of $\mathrm{DaCosta}$ and Beardsley except that in his experience the degree of glycosuria bore no relationship to the extent of the lowering of the opsonic index. Horster (10) working with depancreatized dogs concluded that in these there was a functional disturbance of the leukocytes.

Moen and Reimann (15) found that antibody production (typhoid agglutinins) was lower in patients with diabetes than in normal individuals, in proportion to the severity of the disease. Richardson (9) in a similar study of 42 diabetics and 39 non-diabetics came to the same conclusion. $\mathrm{He}$, too, found that the poorer the control of the diabetes, the lower the agglutinin production. Wale and Madders (16), however, working with staphylococcal toxoid, found that diabetic blood had essentially the same amount of natural staphylococcal antitoxin and that following toxoid treatment, it developed virtually the same increase in antitoxin as normals did.

Richardson (9) found that regardless of blood sugar level, diabetic blood had, in general, a lower bactericidal power than normal blood. The differences were not striking, however. In later work the same investigator (8) found that "underfed" rabbits with low liver glycogen showed lower typhoid agglutinin titers than did wellfed controls with higher liver glycogen. Hyperglycemia maintained by repeated doses of epinephrine had no significant influence on titers. He suggests that the lowered resistance of the diabetic may arise from a "disturbed cellular nutrition closely associated with the diminution of cellular glycogen reserve."

\section{PRELIMINARY EXPERIMENTS}

In an attempt to develop a suitable technique, various procedures were followed in the early part of the present study. Our purpose was to find a method by which we could demonstrate a significant difference in the behavior toward bacteria of diabetic blood, cells, or serum, as compared with that of normal individuals.
At first, using the method of Ward and Enders (17) and freshly isolated strains of staphylococci and streptococci, the opsonizing power of the fresh, defibrinated blood of 10 diabetic patients was compared with that of normal controls. Using all possible combinations of washed normal and diabetic cells plus normal and diabetic sera, no significant tendency was found in favor of any combination. With the 2 strains of staphylococci used, the 2 types of sera and cells exhibited essentially the same marked phagocytic activity, and with 2 strains of streptococci (Lyons " $M$ " strains), both kinds of blood were equally ineffective.

Tests designed to show differences in bactericidal power between normal and diabetic (defibrinated) blood using the method of Todd as modified by Ward (18) were equally inconclusive. We were unable to demonstrate even the slight differences between normal and diabetic blood reported by Richardson (9).

\section{MATERIALS AND METHODS}

The procedures eventually used for the bulk of the study represented attempts to show differences between blood from normal individuals and from diabetic patients by comparing the bacteriostatic, bactericidal, and phagocytizing action of the two types of blood upon Beta hemolytic streptococci. Since the preliminary experiments involving longer incubation had given essentially negative results, these later methods were designed chiefly to reveal any difference in bacteriostatic action initially (i.e., within 2 to 6 hours) as demonstrated by a preliminary lag in bacterial growth. If such an early inhibition could be demonstrated with normal and not with diabetic blood, the results might be used to explain clinical events.

Subjects. The non-diabetic controls were patients from the Outpatient Department of the Beth Israel Hospital, laboratory workers from the Harvard School of Public Health and the New England Deaconess Hospital, and 6 were patients in the Children's Hospital. None had diabetes or, as far as could be determined, any other disease likely to be accompanied by a lowered resistance to infection. The diabetics were all patients in the New England Deaconess Hospital. The ages varied from 4 months to 65 years in the non-diabetic group and from 10 years to 70 years in the diabetic series.

Bacterial strains. The following strains of Beta hemolytic streptococci were used: $\mathrm{Wa}$, isolated from a human case of empyema, and classified as a member of Lancefield's Group A, Ward and Lyons' colony variant $M$; $\mathrm{Ba}$ and Sc kindly provided by Dr. W. S. Tillett (see his paper (19) for description of these strains); NY5, a culture of the original Dochez scarlet fever strain. Capsules were easily demonstrable in cultures of Strains Wa, $\mathrm{Ba}$, and Sc.

Stock cultures. The strains were cultured in defibrinated horse blood, stored in the cold, and transferred monthly.

Test cultures. Strains used in our tests were transferred at frequent intervals through buffered peptone broth containing 0.1 per cent dextrose. Young cultures, representing 3 to 5 hours' growth at $37^{\circ} \mathrm{C}$. and contain- 
ing an average concentration of 100 million bacteria per cc., were used to provide inocula in the various tests.

Collection of blood. Blood was withdrawn under sterile conditions from a vein in the antecubital space. The time of collection was usually in the late forenoon, 2 to 4 hours after the subject had had breakfast. No correlation between the length of time since food and the bactericidal effect of the blood was evident.

Working with horse blood no measurable difference was found in growth curves whether the blood was defibrinated or heparinized, and in view of the waste in defibrination, heparinized blood was used. The subsequent addition of the bacterial culture to the blood was found to cause clotting unless an excess of heparin was present. A 0.5 per cent solution of heparin in 0.85 per cent sodium chloride solution autoclaved at 10 pounds pressure for 20 minutes was used. The addition of $0.5 \mathrm{cc}$. of this solution to $10 \mathrm{cc}$. of blood prevented clotting for 24 hours if the blood-bacterial mixture was well shaken. Heparin rather than sodium oxalate, sodium citrate, or other anticoagulants was used since the reports of others $(20,21,22,23)$ indicated that in vitro the addition of heparin does not inhibit the growth of bacteria nor does it lower the phagocytic power of the blood.

Procedure for bacteriostatic and phagocytic tests. Five cc. of fresh heparinized whole blood and $0.1 \mathrm{cc}$. of a $10^{-4}$ dilution in broth of a 3 to 5 hour broth culture of streptococci were placed in a sterile $25 \mathrm{cc}$. round bottom flask. A plate count on $0.5 \mathrm{cc}$. of a similar mixture was made immediately to determine the initial concentration of bacteria. Flasks containing test mixtures were then fastened in a horizontal position on a disc in the incubator $\left(37^{\circ}\right.$ C.). Rotation at 10 r.p.m. insured continuous mixing of blood and bacteria during incubation. Pour plate counts using blood agar were made on $0.5 \mathrm{cc}$. samples taken after 2, 4, and 6 hours. Simultaneously with the tests for bacteriostatic action, mixtures were made using $0.5 \mathrm{cc}$. of the same blood and $0.1 \mathrm{cc}$. of undiluted culture to determine phagocytic capacity. The latter mixtures were ro tated in the incubator at $37^{\circ} \mathrm{C}$. for 30 minutes at which time smears were made to obtain phagocytic counts.

Procedure for bactericidal tests. In addition to the tests mentioned under "Preliminary Experiments," further attempts to find a difference between normal and diabetic bloods in terms of bactericidal action were carried out as follows: $2 \mathrm{cc}$. of heparinized whole blood plus $0.1 \mathrm{cc}$. of various dilutions of a 3 to 5 hour broth culture were mixed in flasks. In these tests, the initial and final concentrations of bacteria were determined by diluting $1.0 \mathrm{cc}$. of test mixture quantitatively through $9.0 \mathrm{cc}$. blood broth dilution blanks (one drop of defibrinated normal horse blood in $9 \mathrm{cc}$. of broth). The test period was 24 hours. All mixtures were continuously rotated at $40^{\circ} \mathrm{C}$.

\section{RESULTS}

Bacteriostatic and phagocytic tests. Having determined the most satisfactory type of medium for stock cultures and subcultures, size and age of inoculum, type of flask and hours of sampling by an extensive series of preliminary tests with horse blood, 25 tests on 23 non-diabetic individuals, and 27 tests on 27 diabetic patients were carried out to discover the difference, if any, in the inhibitory action and phagocytic power of the bloods upon Beta hemolytic streptococci. The white blood cells were counted on all samples at the beginning of a test and on most of them at the end. Streptococcus Strain Wa was used in all cases.

\section{TABLE I}

Phagocytizing and inhibitory action of heparinized blood of non-diabetic individuals upon streptococci (Strain Wa.) $\dagger$

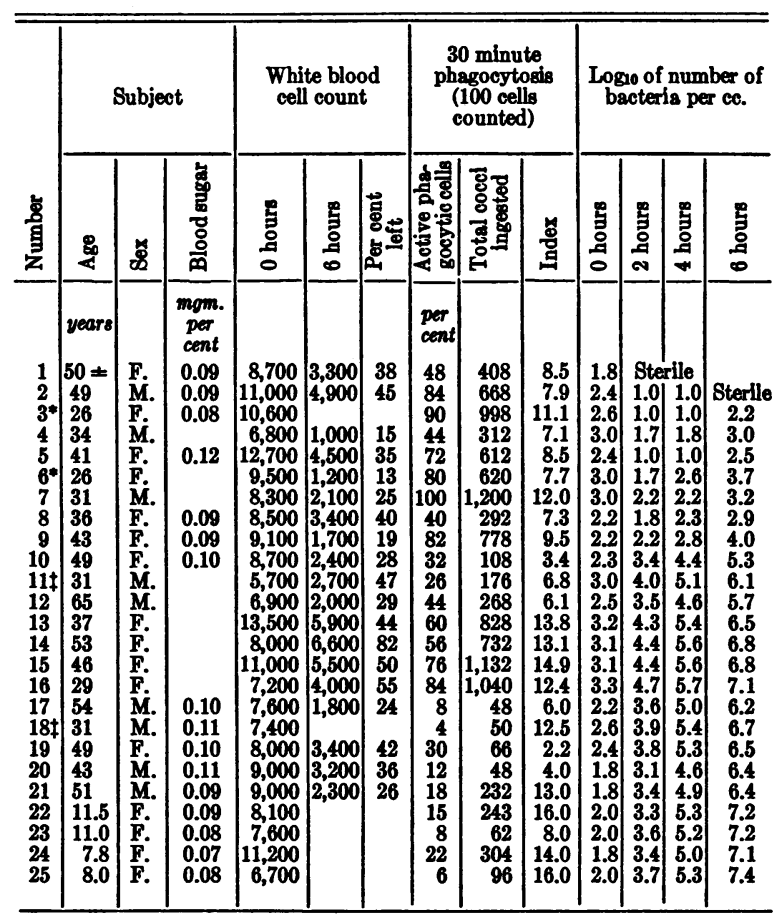

* In Tests 3 and 6 the same subject was used; Test 3 was done 6 weeks after Test 6 .

$\dagger$ Phagocytic and bacteriostatic tests were carried out on separate mixtures simultaneously inoculated.

IIn Tests 11 and 18 the same subject was used; Test 18 was done 6 weeks after Test 11 .

The results obtained with the non-diabetic individuals are shown in Table $I$. Tests $3,4,6,7$, 11,18 were performed upon healthy young laboratory workers. The subjects of Tests 3,6 , and 7 were in daily contact, and that of Test 4 in weekly contact, with the streptococcus used. Tests $1,2,5,8$ to 10,12 to 17,19 to 21 , all inclusive, were on patients from the Outpatient Department of the Beth Israel Hospital and, so far as known, were suffering from no disease which 


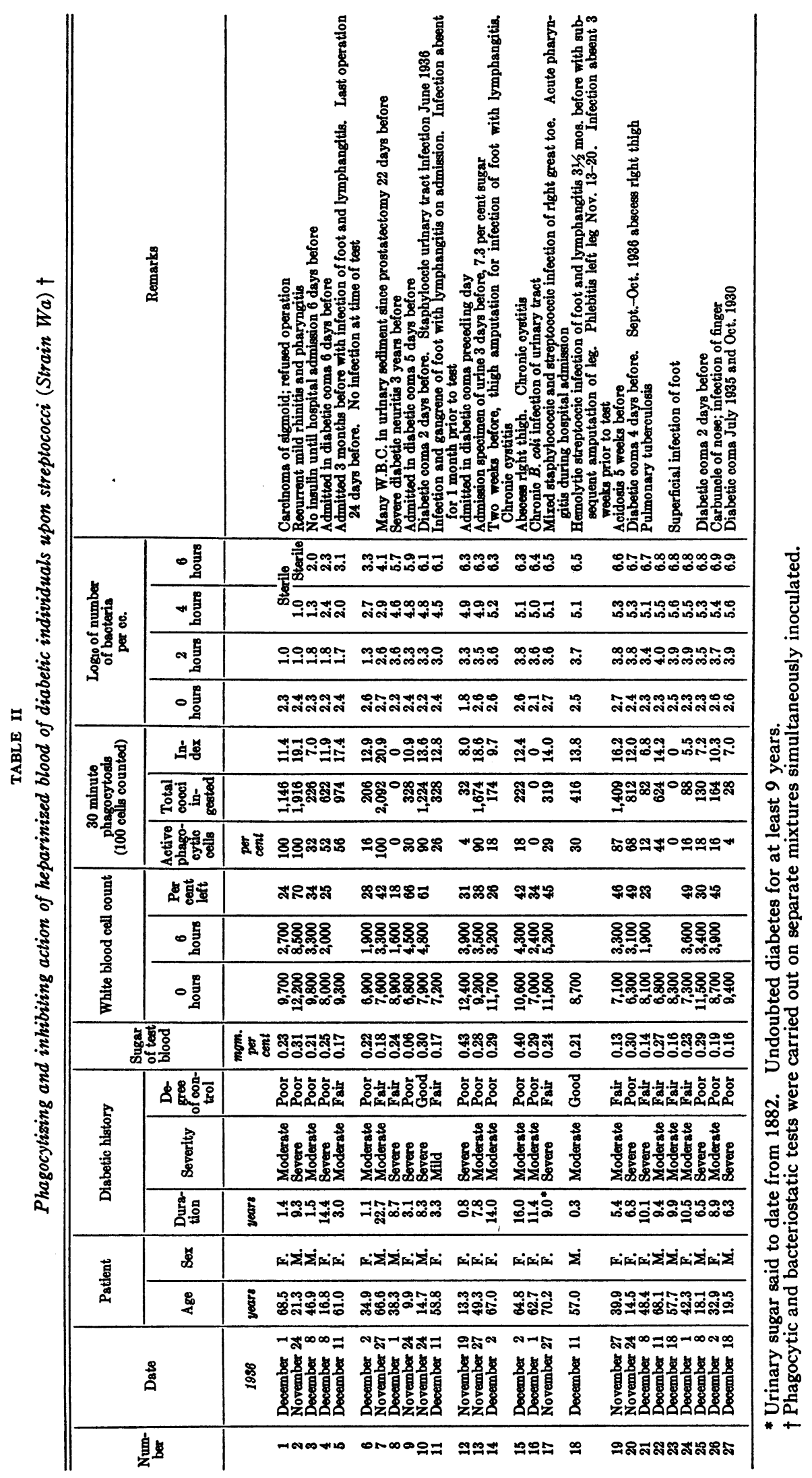


would alter the resistance of the individual to streptococcic infections. The blood Wassermann test was negative in each instance. The children upon whom Tests 22 to 25 were carried out were in-patients on the orthopoedic service at the Children's Hospital. It is fair to state that, because of their physical handicap, these children although suffering from no disease other than structural abnormalities, might not possess average ability to cope with infections. In each case, an attempt was made to ascertain whether the individuals had suffered streptococcic infections in the past. A negative history was obtained in all instances except in the subject of Test 7 who had had a severe streptococcic lymphangitis in the left arm 7 months before, in that of Test 11 who had had streptococcic osteomyelitis 3 years before and that of Test 9 who complained of frequent attacks of pharyngitis.

In all cases the number of white blood cells was definitely decreased at the end of the 6-hour period. Of the 19 tests in which counts were made both at the start and finish, in 3 a final count of less than 20 per cent of the initial was obtained, in 5 from 20 to 29 , in 3 from 30 to 39 , in 5 from 40 to 49 , in 2 from 50 to 59 , and in 1 82 per cent. Tests 4 and 6 in Table $I$ in which the greatest destruction of cells occurred showed respectively 44 and 80 per cent of active phagocytes, whereas the two tests showing the least cell destruction (14 and 16) had 56 and 84 per cent of active phagocytes. The subject in Test 7 (mentioned in the preceding paragraph) showed 100 per cent phagocytosis and 25 per cent survival of white cells and inhibition of growth of the organism for 4 hours. The bacteriostatic effect seen in Tests 3 and 6 possibly reflect the added resistance which this subject acquired through daily contact with the test cultures. Only 2 of the normal bloods ( 1 and 2 ) sterilized themselves within the 6-hour period, and these showed 48 and 84 per cent active phagocytes, respectively.

It is interesting to note that blood of the four children (Tests $22,23,24,25$ ) showed negligible phagocytosis and a logarithmic increase in bacterial population in 6 hours.

The data as regards the diabetic patients are presented in Table II. Twenty-one had initial and final white blood cell counts. Of these, the final count of one was 18 per cent, 5 were from
20 to 29,5 from 30 to 39,7 from 40 to 49,2 from 60 to 69 and 1 was 70 per cent of the initial count. Here as in the normal series there seems to be no correlation between the survival of leukocytes and the efficiency of phagocytosis. In three tests (1, 2,7 ) in which 100 per cent of the leukocytes were actively phagocytic, the percentage surviving at the end of 6 hours was 24, 70, and 42 respectively, and in 2 tests ( 8 and 16) where no cells were actively phagocytic, 18 and 34 per cent of the white blood cells survived. Blood from 2 of the 3 patients showing 100 per cent phagocytosis brought about complete killing of the bacteria in 6 hours, but the third merely inhibited multiplication for 2 hours. One case, 3 , showed an inhibition of growth of the organism for the 6-hour period, but had only 32 per cent active phagocytes. Two cases (4 and 6) showed inhibition of growth for two hours, with phagocytic counts of 52 and 16. The bloods showing the most rapid initial growth of the organism $(12,22,24)$ had phagocytic counts of 4,44 , and 16 respectively.

The 2 diabetic patients whose blood sterilized itself in the flasks were poorly controlled clinically. Case 2 was a young man 21.3 years old, with diabetes of 9.3 years' duration; the blood used in the test had a sugar content of 0.31 per cent. Case 1 was an elderly woman 68.5 years old with diabetes of 1.4 years' duration; the sugar content of her blood used in the test was 0.23 per cent.

Cases 8,16 , and 23 who showed no phagocytosis, all had 2-hour logarithmic increases in bacterial population of 1.4 which is not the greatest increase in the series, nor was their 6-hour bacterial count as high as some $(12,22,24,25)$.

The phagocytic indices of the non-diabetics varied from 2.2 to 14.9 with an average of 9.7 . The 2 bloods ( 1 and 2) which brought about complete killing of the bacteria had phagocytic indices of 8.5 and 7.9. In the diabetic group the indices varied from 0 to 20.9 with an average of 10.9 , with the bactericidal numbers 1 and 2 showing indices of 11.4 and 19.1 .

The results obtained with the bacteriostatic and phagocytic tests are summarized in Table III. As may be seen from Table III no significant difference was apparent between the behavior of diabetic and non-diabetic blood.

Bactericidal power of blood. On completion 
TABLE III

Summary of results of bacteriostatic and phagocytic tests

\begin{tabular}{|c|c|c|c|c|c|c|c|c|c|c|c|}
\hline \multirow{3}{*}{$\begin{array}{c}\text { Type } \\
\text { of } \\
\text { subject }\end{array}$} & \multirow{3}{*}{$\begin{array}{l}\text { Total } \\
\text { num- } \\
\text { ber } \\
\text { of } \\
\text { cases }\end{array}$} & \multicolumn{6}{|c|}{ Bacteriostatic tests } & \multicolumn{4}{|c|}{ Phagocytio tests } \\
\hline & & \multicolumn{2}{|c|}{$\begin{array}{l}\text { Bacterl- } \\
\text { cidal* }\end{array}$} & \multicolumn{2}{|c|}{$\begin{array}{c}\text { Bacterio- } \\
\text { statict }\end{array}$} & \multicolumn{2}{|c|}{$\begin{array}{l}\text { Non- } \\
\text { inhibi- } \\
\text { tory }\end{array}$} & \multicolumn{2}{|c|}{$\begin{array}{c}0 \text { to } 50 \\
\text { per cent } \\
\text { active } \\
\text { phagocytes }\end{array}$} & \multicolumn{2}{|c|}{$\begin{array}{l}51 \text { to } 100 \\
\text { per cent } \\
\text { sctive } \\
\text { phagocyte }\end{array}$} \\
\hline & & $\frac{8}{\text { 莇 }}$ & $\begin{array}{l}\text { 葛 } \\
\text { 总 } \\
\end{array}$ & $\frac{8}{8}$ & 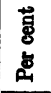 & $\frac{8}{8}$ & 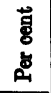 & $\frac{\text { 嘼 }}{2}$ & $\begin{array}{l}\overrightarrow{8} \\
8 \\
\text { D }\end{array}$ & 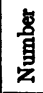 & $\begin{array}{l}\text { 若 } \\
\text { 。 }\end{array}$ \\
\hline Non-diabetio. & 23 & 2 & 8.7 & 6 & 26.1 & 15 & 65.2 & 14 & 60.9 & 9 & 39.1 \\
\hline Diabetio..... & 27 & 2 & 7.4 & 5 & 18.5 & 20 & 74.1 & 18 & 66.7 & 9 & 33.3 \\
\hline
\end{tabular}

* Bactericidal: sterility in 6 hours.

$\dagger$ Bacteriostatic: inhibitory to such a degree that the original population decreased at least during the first 2 hours and in most instances was either less or only slightly greater in 4 hours.

of the work described above it was felt that the bacteriostatic and phagocytic tests did not indicate clearly any significant difference between the circulating blood of the diabetic and the nondiabetic individuals studied. Further attempts to demonstrate such a difference in terms of bactericidal action were then carried out.

Four bacterial strains were used: Wa, Ba, Sc and NY5 (see description of organisms under "Materials and Methods"). The blood of 12 non-diabetic and 6 diabetic individuals was available. As can be seen readily from Table IV, the results obtained were essentially the same in the two groups. Both had difficulty in exerting complete bactericidal action upon the resistant $\mathrm{Wa}$ and $\mathrm{Ba}$ strains and dealt about equally well with the less resistant strains Sc and NY5. One of the diabetic bloods (Number 3 ) killed all four organisms in 24 hours. This patient is a diabetic of long standing, the first in Boston and perhaps in the United States to take insulin (on August 7, 1922) and her diabetes has never been under exceptional control. It should be noted that these tests were carried out at $40^{\circ} \mathrm{C}$. With each test a horse blood control mixture was run on each organism at $40^{\circ} \mathrm{C}$. and in no case did it fail to grow.

Using Strain Sc which all bloods tested killed at $40^{\circ} \mathrm{C}$. in a $10^{-4}$ dilution of a 4 -hour broth culture, an attempt was made to determine whether normal blood would kill a larger inoculum of this organism than diabetic blood. The results are shown in Table V.

Of the 5 normals, Number 5 affected the culture in all dilutions but merely inhibited the un-
TABLE IV

Effect of human blood upon streptococci (Strains Wa, Ba, Sc, NY5) at $40^{\circ} C .^{*}$

\begin{tabular}{|c|c|c|c|c|c|c|c|c|}
\hline \multirow{2}{*}{$\begin{array}{c}\text { Blood } \\
\text { specimen } \\
\text { number }\end{array}$} & \multicolumn{4}{|c|}{3 hours' incubation } & \multicolumn{4}{|c|}{24 hours' incubation } \\
\hline & $\begin{array}{c}\text { Strain } \\
\text { Wa }\end{array}$ & $\underset{\mathrm{Ba}}{\text { Strain }}$ & $\begin{array}{c}\text { Strain } \\
\text { Sc }\end{array}$ & $\begin{array}{l}\text { Strain } \\
\text { NY5 }\end{array}$ & $\begin{array}{c}\text { Strain } \\
\text { Wa }\end{array}$ & $\underset{\mathbf{B a}}{\text { Strain }}$ & $\begin{array}{c}\text { Strain } \\
\text { Sc }\end{array}$ & $\begin{array}{l}\text { Strain } \\
\text { NY5 }\end{array}$ \\
\hline
\end{tabular}

A. NORMAL CONTROLS

\begin{tabular}{c|c|c|c|c|c|c|c|c}
\hline 1 & $\times$ & $\times$ & + & $\times$ & $\times$ & $\times$ & + & $\times$ \\
2 & 0 & $\times$ & + & $\times$ & 0 & $\times$ & + & $\times$ \\
3 & + & + & + & + & + & + & + & $\times$ \\
4 & 0 & $\times$ & + & + & 0 & $\times$ & + & $\times$ \\
5 & 0 & $\times$ & + & + & 0 & $\times$ & + & $\times$ \\
6 & + & + & + & + & + & + & + & $\times$ \\
7 & 0 & 0 & + & $\times$ & 0 & 0 & + & $\times$ \\
8 & $\times$ & $\times$ & + & $\times$ & + & $\times$ & + & + \\
9 & 0 & $\times$ & + & + & $\times$ & $\times$ & + & $\times$ \\
10 & $\times$ & $\times$ & + & + & $\times$ & $\times$ & + & + \\
11 & 0 & $\times$ & + & $\times$ & 0 & $\times$ & + & + \\
12 & $\times$ & $\times$ & + & $\times$ & $\times$ & $\times$ & + & + \\
\hline Totals & $2+$ & $2+$ & $12+$ & $6+$ & $3+$ & $2+$ & $12+$ & $4+$ \\
& $4 \times$ & $9 \times$ & $0 \times$ & $6 \times$ & $4 \times$ & $9 \times$ & $0 \times$ & $8 \times$ \\
\hline
\end{tabular}

B. DIABETIC PATIENTS

\begin{tabular}{|c|c|c|c|c|c|c|c|c|}
\hline $\begin{array}{l}1 \\
2 \\
3 \\
4 \\
5 \\
6\end{array}$ & $\begin{array}{c}0 \\
\times \\
\times \\
0 \\
0 \\
0\end{array}$ & $\begin{array}{l}x \\
x \\
+ \\
\dot{x} \\
\dot{x} \\
x\end{array}$ & $\begin{array}{l}+ \\
+ \\
+ \\
\dot{x} \\
\dot{x} \\
\dot{x}\end{array}$ & $\begin{array}{l}x \\
\dot{x} \\
\dot{x} \\
\dot{x} \\
\dot{x} \\
x\end{array}$ & $\begin{array}{l}0 \\
+ \\
+ \\
\mathbf{0} \\
\mathbf{0} \\
0\end{array}$ & $\begin{array}{l}x \\
x \\
+ \\
\dot{x} \\
\dot{x} \\
\dot{x}\end{array}$ & $\begin{array}{l}+ \\
+ \\
+ \\
+ \\
+ \\
+\end{array}$ & $\begin{array}{l}+ \\
+ \\
+ \\
+ \\
+ \\
+ \\
+\end{array}$ \\
\hline Totals & $\begin{array}{l}0+ \\
2 \times \\
40\end{array}$ & $\begin{array}{l}1+ \\
5 \times \\
00\end{array}$ & $\begin{array}{l}3+ \\
3 \times \\
00\end{array}$ & $\begin{array}{ll}0+ \\
6 \times \\
0 & 0\end{array}$ & $\begin{array}{l}2+ \\
0 \times \\
40\end{array}$ & $\begin{array}{ll}1+ \\
5 \times \\
0 & 0\end{array}$ & $\begin{array}{l}6+ \\
0 \times \\
00\end{array}$ & $\begin{array}{ll}6+ \\
0 & x \\
0 & 0\end{array}$ \\
\hline
\end{tabular}

$*+=$ Bactericidal effect, i. e., no growth in subculture of test mixture.

$X=$ Bacteriostatic effect, $i$. e., slight or no increase over initial concentration of bacteria.

$0=$ No inhibitory effect, $i . e .$, logarithmic increase in concentration of bacteria.

diluted inoculum. The others except for Number 1 , were not very effective. In the diabetic series, 2 were bactericidal in all dilutions, while 4 were bacteriostatic for the undiluted inoculum and either bacteriostatic or bactericidal in the lower dilutions. Hence here again no significant difference between the behavior of diabetic and nondiabetic blood was demonstrable.

\section{DISCUSSION}

The results just outlined are of an essentially negative character in that they show no significant difference between the bactericidal, bacteriostatic, or phagocytic power of diabetic as compared with normal blood. They demonstrate that if one car- 
TABLE $V$

Effect of human blood upon streptococci (Strain Sc) at $40^{\circ} \mathrm{C}$. for 24 hours*

\begin{tabular}{l|l|l|l|l|l}
\hline \hline & \multicolumn{4}{|c}{ Dilutions of 3-hour culture of streptococci } \\
$\begin{array}{l}\text { Blood speci- } \\
\text { men number }\end{array}$ & Undiluted & $10^{-1}$ & $10^{-2}$ & $10^{-8}$ & $10^{-4}$ \\
\hline
\end{tabular}

A. NORMAL CONTROLS

\begin{tabular}{l|l|l|l|l|l}
\hline 1 & & + & + & + & + \\
2 & 0 & 0 & 0 & & \\
3 & 0 & 0 & + & & \\
4 & 0 & + & + & & \\
5 & $\times$ & + & + & & \\
\hline
\end{tabular}

B. DIABETIC PATIENTS

\begin{tabular}{r|c|c|c|c|c}
\hline 1 & & 0 & + & + & + \\
2 & 0 & 0 & 0 & & \\
3 & + & + & + & & \\
4 & 0 & 0 & 0 & \\
5 & 0 & + & + & \\
6 & $\times$ & + & + & \\
7 & 0 & $\times$ & + & \\
8 & $\times$ & $\times$ & + & \\
9 & $\times$ & $\times$ & & \\
10 & $\times$ & $\times$ & + & & \\
11 & + & + & + & & \\
\hline
\end{tabular}

$*+=$ Bactericidal effect, $i . e .$, no growth in subculture of test mixture.

$X=$ Bacteriostatic effect, $i$. e., slight or no increase over initial concentration of bacteria.

$0=$ No inhibitory effect, $i . e .$, logarithmic increase in concentration of bacteria.

ries out such tests using a few selected strains of streptococci, approximately the same variation of bactericidal or phagocytic power will be found among a group of diabetic patients, regardless of duration, severity, or state of control of the diabetes, as among a group of normal individuals selected at random. This variation is without doubt partly dependent upon former chance contacts, chiefly during infections, between the individuals concerned, diabetic or non-diabetic, and the specific (or to a less extent, related) bacterial strains used. Among other factors, aside from the possible influence of diabetes itself, is the variable capacity of individuals to respond to antigenic contacts. Our findings suggest that diabetic patients who successfully combat past infections thereby develop specific immunity to roughly the same extent as do non-diabetic controls. It is true that Moen and Reimann (15) and Richardson (8), in work already referred to, found the development of typhoid agglutinins poorer in diabetic than in normal individuals. Corresponding studies using streptococci or their products cannot be carried out so that one must be content with the type of data presented in the present paper. Furthermore, we believe that the development of agglutinins is not as significant from the point of view of actual protection as the type of immunity demonstrable by the methods employed in the present study.

It must be emphasized that our results were obtained by the use of a few selected bacterial strains. Different findings might possibly be secured using other techniques and other organisms, but the possibilities in this regard are many, and in view of the frankly negative character of the results to date, we have not thought it worth while to pursue the question along this line.

Wherein, then, does the lowered resistance to infection of the uncontrolled diabetic lie? We have already conceded that the well-controlled patient may exhibit an essentially normal defense. It seems likely that the commonly occurring malnutrition, dehydration, and acidosis of the poorly controlled diabetic may contribute to poor resistance in a manner which is not reflected in the type of study here reported. Perhaps also one should consider more specifically the functional integrity of the fixed tissue cells, i.e., the mononuclear cells of the reticulo-endothelial system. Their important rôle in bodily defense no one will deny. One is intrigued by the possibility that, in the uncontrolled diabetic, the hypercholesterinemia which is present not infrequently, may be associated with a "blockade" of the reticulo-endothelial system with consequent lowering of its efficiency. Upon this point data are difficult to acquire and our own experiments are not relevant.

\section{CONCLUSIONS}

Fresh defibrinated blood and heparinized whole blood of diabetic patients were found to possess essentially the same phagocytic, bacteriostatic, and bactericidal power against selected strains of streptococci as blood from normal controls. Results in individual cases could not be correlated with the duration, severity, or state of control of the diabetes.

The authors are grateful to Dr. L. D. Fothergill for valuable suggestions, to Dr. W. G. Smillie for granting the use of his laboratory for a part of the work, and to Drs. H. L. Blumgart, H. A. Derow and A. M. Butler for 
allowing access to certain patients used as normal controls.

\section{BIBLIOGRAPHY}

1. Lassar, O., Ernährungstherapie bei Hautkrankheiten. Dermat. Ztschr., 1904, 11, 189.

2. Handmann, E., Utber die Ursache der verminderten Resistenz des Diabetikers gegen Infektionen. Deutsches Arch. f. klin. Med., 1911, 102, 1.

3. Hirsch-Kauffmann, H., and Heimann-Trosien, A., Bakterienwachstum auf dem Blut Diabetischer Kinder. Klin. Wchnschr., 1926, 5, 1922.

4. Kestermann, E., and Knolle, A., Über die baktericide Wirksamkeit des Diabetikerserums. Deutsches Arch. f. klin. Med., 1933, 176, 65.

5. Pillsbury, D. M., and Kulchar, G. V., The relation of experimental skin infection to carbohydrate metabolism. The effect of hypertonic glucose and sodium chlorid solutions injected intraperitoneally. Am. J. M. Sc., 1935, 190, 169.

6. Mosenthal, H. O., Hyperglycemia. Evaluation in the treatment of diabetes mellitus. J. A. M. A., 1935, 105, 484.

7. Bayne-Jones, S., The effects of carbohydrates on bacterial growth and development of infection. Bull. New York Acad. Med., 1936, 12, 278.

8. Richardson, R., Immunity in diabetes. II. Relative importance of nutritional state and of blood sugar level in influencing development of the agglutinin after typhoid vaccine. J. Clin. Invest., 1935, 14, 389.

9. Richardson, R., Immunity in diabetes: Influence of diabetes on the development of antibacterial properties in the blood. J. Clin. Invest., 1933, 12, 1143.

10. Horster, H., Untersuchungen über die durch Krankheiten hervorgerufene Änderung der Disposition für Infection bzw. für Erkrankung nach Infection. Beitrag zur Klärung der Ursache der verminderten Widerstandsfahigkeit des zuckerkranken Organisms gegen Infection. Deutsches Arch. f. klin. Med., 1934, 176, 502.

11. Bayer, G., and Form, O., Zusammenfassung von Studienergebnissen (am Krankenbett und im Laboratorium). Uber den Einfluss des Insulins auf die Phagozytose im Tierkörper und auf Komplementgehalt. Deutsches med. Wchnschr., 1926, 52, 1338.
12. DaCosta, J. C., Jr., and Beardsley, E. J. G., The resistance of diabetics to bacterial infection. A study of the opsonophagocytic properties of the blood in 74 cases of diabetes mellitus and related conditions. Am. J. M. Sc., 1908, 136, 361.

13. DaCosta, J. C., Jr., The opsonic index in diabetes mellitus. A preliminary record of the findings in 22 cases of glycosuria, with remarks on the technique of the opsonin test and on its clinical utility. Am. J. M. Sc., 1907, 134, 57.

14. Sisto, P., Ricerche sul potere opsonico del siero di sangue nei diabetici. Clin. med. ital., 1911, 50, 301.

15. Moen, J. K., and Reimann, H. A., Immune reactions in diabetes. Arch. Int. Med., 1933, 51, 789.

16. Wale, R. S., and Madders, K., Staphylococcal toxoid in the treatment of diabetes. Brit. J. Exper. Path., 1936, 17, 279.

17. Ward, H. K., and Enders, J. F., An analysis of the opsonic and tropic action of normal and immune sera based on experiments with the pneumococcus. J. Exper. Med., 1933, 57, 527.

18. Ward, H. K., Observations on the phagocytosis of the pneumococcus by human whole blood. J. Exper. Med., 1931, 51, 675.

19. Tillett, W. S., The bactericidal action of human serum on hemolytic streptococci. I. Observations made with serum from patients with acute infections and from normal individuals. J. Exper. Med., 1937, 65, 147.

20. Boerner, V. M. D., and Mudd, S., Determination of the phagocytic power of whole blood or plasmaleukocyte mixtures for clinical or experimental purposes. Description of an improved method with representative findings. Am. J. M. Sc., 1935, 189, 22.

21. Mahorner, H. R., and Ochsner, A., Bactericidal effect of hirudin and heparin. II. Growth of organisms in blood rendered incoagulable with hirudin and heparin. Arch. Surg., 1935, 31, 371.

22. Wright, H. D., Cited by Solis-Cohen, M., Determining infectivity of bacteria for their host with special reference to pathogen-selective culture. Lancet, 1936, 2, 1447.

23. Veazie, L., and Meyer, K. F., Heparin as an anticoagulant in the brucella phagocytic index test. Proc. Soc. Exper. Biol. and Med., 1935, 32, 1616. 